\title{
LEGAL AND SOCIAL COMPLEXITIES RELATING TO PRACTICE OF ARRANGED AND FORCED MARRIAGES
}

\begin{abstract}
Ashraf Booley ${ }^{1}$
ABSTRACT

The practice of forced and/or arranged marriages are reported to be taking place globally. These types of marriages have become gender neutral and can no longer be described only as an issue relating to women. However, what is portrayed is that women normally suffer as reported cases are evidence of that. First world countries where there is a large immigrant community, frown on the practice of forced marriages and arranged marriages. This is a complex issue, because on the one hand, one's religious, cultural diversity is attacked and on the other hand forced and arranged marriages may violate various provisions of international, regional national human rights instruments. From an international law perspective, one could argue that there is a clear violation of international law. On the other hand, and argument relating to one's cultural and religious beliefs could also be advanced. Concepts such as culture, religion and gender are deeply embedded in most known religions and communities, therefore, the practice of forced and arranged marriages may not be perceived as violation of any law/s whether international or national. Furthermore, forced and arranged marriages are at times so interrelated that it may be difficult to draw a clear
\end{abstract}

Senior Lecturer, Department of Private Law, University of the Western Cape, South Africa. abooley@uwc.ac.za 
distinction between the two. How do we protect women's rights while at the same time respecting the cultural diversity of society? This article attempts to add to the existing debate surrounding the social and legal complexities of forced and arranged marriages.

Keywords: forced marriage, arranged marriages, human rights, culture and gender, religion and violation

\section{INTRODUCTION}

Historically, marriage by definition is normally entered into as a planned and, long-term relationships between individuals. ${ }^{2}$ It may be suggested that for a marriage to succeed, a certain amount of effort is required coupled with a vital aspect that is the emotional and physiological aspect of marriage, and therefore, a marriage should be concluded with the individual's consent. Consent should idyllically be of free, unfettered, and unhindered consent. Forced and arranged marriages may disadvantage women of all ages of their most basic and fundamental human rights. However, forced and arranged marriages is a sensitive and complex issue, which has existed for centuries. ${ }^{3}$ Forced and arranged marriages of males is rare, but it does happen, sadly, forced marriages is mainly, aim towards females. ${ }^{4}$

Kaplan argues that marriage of daughters in some conservative societies originates from a stereotypical perspective that a women's locus is her home, her role as childbearing, mother as well as educating and growth of the child/ children. ${ }^{5}$ Of note forced and arranged marriages can also be described as an act of control by senior men and women in the family. Therefore, another contributing factor relating to the issue of arranged and forced marriages is the role of the family. However, one must also be sensitive to the issues of society as not to offend certain practices which has been in existence before the introduction of various international, regional, and national laws relating to the

2 Gill A.K. \& Hamed T., 'Muslim Women and Forced Marriages in the UK,' Journal of Muslim Minority Affairs, vol. 36/4 (2016): 540-560.

3 Mtshali V., 'Forced Child Marriage Practiced under the Pretext of Customary Marriage in South Africa,' Child Abuse Research: A South African Journal, vol. 15/2 (2014): 51-61.

4 Kaplan Y.S., 'A Father's Consent to the Marriage of his Minor Daughter: Femininsm and Multiculturalism in Jewish Law,' Review of Law and Social Justice, vol. 18/2 (2009): 393-460.

5 Kaplan Y.S., 'A Father's Consent to the Marriage of his Minor Daughter: Femininsm and Multiculturalism in Jewish Law,' 393-460. 
protection and enhancement of the human being. Although, the requirement for the free and informed consent of the parties to the marriage is acknowledged in numerous international, regional, national levels, however, despite such acknowledgement, limited countries have criminalized this type of behaviour.

This article will look at certain constructs that may play an important factor contributing towards the practice of forced and arranged marriages in a broader social context. In addition, the practice of forced and arranged marriages in the sphere of international regional and national laws, forced and arranged marriages as a form of slavery, and finally legal initiatives for the prevention of these practices. Unfortunately, this article cannot cover all issues which may have an impact and contributing to those practices. Sadly, regardless of existing opposition and law/s, such practices persist. ${ }^{6}$ In most instances, forced and arranged marriages are tied to constructs such as culture, gender and religion, which will be discussed next.

\section{CONSTRUCTS SUCH AS CULTURE, RELIGION AND GENDER}

\section{Culture}

Constructs such as culture, religion and gender could be referred to as a social behavioural characteristic by amongst various communities. In addition, these constructs are profoundly embedded as sociocultural trends. Culture may be described as a macro-concept because it is definitive of human society, according to Raday. ${ }^{7}$ Anthropologists habitually use the term 'culture' to refer to a society or group in which many or all people live and think in the same way/s. ${ }^{8}$ Furthermore, any group of people who are part of a common culture and in particular, common rules of behaviour may constitute a society. Kuper states, that in its most general sense culture is simply a way of talking of identities. ${ }^{9}$ Inferences may be drawn that patriarchal cultures, relating to the treatment of women, are perhaps necessarily contrary to the notion of modernday human rights doctrines. ${ }^{10}$ There will only be collisions when these cultures resist and are raised as a cultural defence relating to the practice of arranged

6 Thomas C., 'Forced and Early Marriage: A Focus on Central and Eastern Europe and Former Soviet Union Countries with selected Laws from Other Countries,' United Nations Division for the Advancement of Women (2009): 1-19.

7 Raday F., 'Culture, Religion, and Gender,' International Journal of Constitutional Law, vol. 1/4 (2003): 663-715.

8 Raday F., 'Culture, Religion, and Gender,' 663-715.

9 Kuper A., Culture: The Anthropologists' Account (Massachusetts: Harvard University Press, 1999), 1-320.

10 Raday F., 'Culture, Religion, and Gender,' 663-715. 
and forced marriages. A possible solution would be the following. If culture acknowledges human rights as an instrument for equality, there could be a process of interactive development and no need for confrontation between culture and a human rights development in a broader conversational and legal context. This could perhaps lead to a better understanding and educating communities when it comes to the practice of arranged and forced marriages in the future.

\section{Religion}

In many aspects, religion and culture as concepts and practices may be interrelated in the wider sense. Burkert, states that there has never been a society without religion. ${ }^{11}$ The question here is what constitutes religion, and again one must be extremely sensitive to this issue. One classical work on the subject highlighted that there are almost forty-eight different definitions of religion. ${ }^{12}$ Usually such definitions include evidence of transcendental belief in or affiliation of the divine. ${ }^{13}$ Modern day scholars regard the concept of religion to include nontheistic as well as atheistic adherences. ${ }^{14}$

However, in practice, claims against gender equality has been under the umbrella of the most dominant monotheistic religions, such as, Islam, Judaism, Christianity and Hinduism, although there is no closed list. The unique traits of monotheistic scriptural religions are clear, that tend to a have canonical text with authoritative interpretations and applications, a division of officials to uphold and spread the faith, a defined legal structure, and ethical norms for the commandment of the daily lives of the individual and communities. ${ }^{15}$ Therefore, religion can be seen as an institutional aspect of culture, with bureaucratic institutions that are a central point for economic, social and political power within society, because of these focal points, religion is less amendable to adaptions from the outside influences. For a change to occur, it must first happen within the so-called religious hierarchy of the various communities and must then be shown to conform to the religious doctrines of the various written sources. Within secular nations, religious sects often

11 Burkert W., Creation of the Sacred: Tracks of Biology in Early Religions (Cambridge, Massachusetts: Harvard University Press, 1996), 1-320.

12 Cohn H., 'Religious Human Rights,' 19 Dine Israel 101 (1997-1998), http:// religionhumanrights.org, accessed on 19 June 2019.

13 Raday F., 'Culture, Religion, and Gender,' 663-715.

14 Cohn H., 'Religious Human Rights.'

15 Raday F., 'Culture, Religion, and Gender,' 663-715. 
act as a haven against social and cultural change in that they preserve ethnic commitments, the authority of the larger family groupings and act as a bastion against sensible educational understandings and perhaps a broader gender interpretation.

\section{Gender}

According to Raday, gender is a social construct of sex. ${ }^{16}$ Sexual identity, may result from the differing physiological characteristics of male and female, whereas, gender identity may result from behavioural attitudes imposed on men and women, for example, by culture, religion and communities. The issue of gender in religion, traditional and conservative cultures, is the standardized control of men over women, the exclusion of women from holding public power as well as family patriarchy by both men and women, when it comes to marriage. It is however, important to realise that culture and religion existed long before the issue of human rights came about. It was not until the Enlightenment period that a human rights ideology for the recognition of women's right to equal citizenship was entrenched and much later in the twentieth century that women's right to equality gathered momentum. ${ }^{17}$ Sadly, still in the twenty-first century, traditional and conservative cultures are seen as steadfast bastions of certain patriarchal values and practices. Evidence may be deduced that cultural and religious defences are frequently employed, in an attempt, to restrain the rise of women's equality within a broader legal and religious context.

Here again, perhaps a possible solution relating to the practice of arranged and forced marriages would be to encourage those communities, by leaders of the various religious groupings in the form of informing those of possible pitfalls and harm that may averted. We will now focus on forced marriages.

\section{THE DEFINITION OF FORCED MARRIAGE}

Recently, the notion of forced and arranged marriages has been under the spotlight and subject to much public and political debate throughout Europe. This is due to reports that immigrant females in Western European countries have been removed and taken to their country of origin to marry against their

\footnotetext{
16 Raday F., 'Culture, Religion, and Gender,' 663-715.

17 Raday F., 'Culture, Religion, and Gender,' 663-715.
} 
will or perhaps under false pretences. ${ }^{18}$ In 2006, the then United Nations Secretary-General Kofi Annan defined forced marriage as one that, "lacks the free and valid consent of at least one of the parties". He continues; "In its most extreme form, forced marriage can involve threatening behaviour, abduction, imprisonment, physical violence, rape and in some cases murder. There has been little research on this form of violence". ${ }^{19}$

According to the Women Living Under Muslim Laws (WLUML) ${ }^{20}$ the abovementioned definition is consistent with the most often used, if not the disordered, interpretation of forced marriages used by practitioners, campaigners and scholars; the absence of free consent, of at least one of the parties, and in the most extreme of situations both parties. ${ }^{21}$ In addition, the definition lends itself to the issue that forced marriages constitute genderbased violence and incorporates women's vulnerability, as well as the violation of women's freedoms and fundamental rights which is protected on the international plane. However, forced marriages is no longer gender specific, but becoming gender neutral and perhaps most importantly becoming faith and cultural neutral.

The differentiation of arranged marriages and forced marriages is not a simple task. An attempt will be made to highlight differences between these two types of practices. Both types of marriages are steeped in culture and/or religion or perhaps both and is often stemming from minority groups in a country (not of the individual/s origin), but perhaps from dominant communities as well. Again, one has to be sensitive not to prescribe the views of others while these are practices that have been practiced for centuries.

In broad strokes an arranged marriage takes place where the parents or extended family select a potential suitor, however, the issue of consent is

18 Sabbe A., Temmerman M., Brems E. \& Leye E., 'Forced Marriage: An Analysis of Legislation and Political Measures in Europe,' Crime, Law and Social Change, vol. 62/2 (2014): 171-189.

19 Women Living under Muslim Laws, 'Child, Early and Forced Marriage: A MultiCountry Study,' A Submission to the UN Office of the High Commissioner on Human Rights (OCHCR) (London: Women Living under Muslim Laws, 2013$), 2$.

20 Women Living under Muslim Laws (WLUML) is an international solidarity network that provides information, support and a collective space for women whose lives are shaped, conditioned or governed by laws and customs said to be derive from Islam.

21 Women Living under Muslim Laws, 'Child, Early and Forced Marriage: A MultiCountry Study,' 2. 
still the prerogative of the parties to the arranged marriage. ${ }^{22}$ In contrast, for forced marriages, it is argued that there is no consent, whether free or full, or informed, however, the involvement of the family is dominant in finding not only a suitor but the suitor is the choice of the family. In other words, the suitor is regarded as the family's prerogative and not the prerogative of the woman to the marriage. Forced marriages are said to interwoven with migration and in some cases be associated with potential domestic violence. ${ }^{23}$ According to Sabbe, Temmerman, Brems and Leye, they note that the media has highlighted that forced marriages and ancillary issues such as the concept of family honour and the taking of a live in the name of the family are often referred to as honour killings. ${ }^{24}$ Reddy, postulates that honour killings refers to where a "woman is killed to either prevent or repair perceived violations of familial honour". ${ }^{25}$

The institution of 'honour' is linked to sexual morality, the behavioural aspect in most incidents relating only to women. ${ }^{26}$ Honour is understood as the sexual integrity and chastity of only women within the family, for example, mothers, wives, sisters and daughters. As honour is viewed as residing in the female, it seems to operate to control, direct and regulate the women's affairs from birth into marriage and perhaps further. ${ }^{27}$ However, for males this does not apply. The male has freedom to do as he wants within the boundaries of religion only, and it seems evident from a community perspective that allows that type of behaviour. ${ }^{28}$ Therefore, one could argue that forced marriages is said to be closely linked to that of an 'honour crime' in itself, and the precursor to or result of other formats of honour related violence. ${ }^{29}$ For example, social

22 Chantler K., 'Recognition of and Intervention in Forced Marriages as a Form of Violence and Abuse,' Sage Journals: Trauma, Violence, \& Abuse, vol. 13/3 (2012): 176-183.

23 Sabbe A., Temmerman M., Brems E. \& Leye E., 'Forced Marriage: An Analysis of Legislation and Political Measures in Europe,' 171-189.

24 Sabbe A., Temmerman M., Brems E. \& Leye E., 'Forced Marriage: An Analysis of Legislation and Political Measures in Europe,' 171-189.

25 Reddy R., 'Gender, Culture and the Law: Approaches to Honour Crimes in the UK,' Feminist Legal Studies, vol. 16/3 (2008): 305-321.

26 Women Living under Muslim Laws, 'Child, Early and Forced Marriage: A MultiCountry Study,' 13.

27 Women Living under Muslim Laws, 'Child, Early and Forced Marriage: A MultiCountry Study,' 13.

28 Women Living under Muslim Laws, 'Child, Early and Forced Marriage: A MultiCountry Study,' 13.

29 Reddy R., 'Gender, Culture and the Law: Approaches to Honour Crimes in the UK,' 305-321. 
and economic for her as well as her family and may also result in death. What lies at the heart of the debate relating to arranged and forced marriages are issues such as "full and free consent" and "coercion". We will focus on the distinction between the practices of arranged and forced marriages.

\section{THE DISTINCTION BETWEEN ARRANGED AND FORCED MARRIAGE}

Forced marriages may be apparent in either a subtle or more blatant mode. ${ }^{30}$ The most appalling evidence would be the selling of women into marital contracts, forcing women to marry in some instances their rapists in order to restore the families honour and the involvement of relatives compelling women to get married. ${ }^{31}$ Relatives in the case of forced marriages can manifest itself as being gender neutral. In contrast, subtle practices may include family and societal influences to contract a marriage if the women is pregnant. ${ }^{32}$ Conformity is often sought through coercion or the use of violence by a family member/s, and perhaps in extreme situations the extended family (aunts and uncles). A forced marriage can therefore be characterised as a marriage in which either one or both parties has been coerced without giving their free and full consent. ${ }^{33}$ Coercion is a legal term denoting 'duress'. ${ }^{34}$ According to Nyazee, 'coercion as a situation in which one is forced to do something without his or her willingness.' ${ }^{35}$ Therefore, for coercion to be present, two factors must be present, one is physical - the threat of inflicting harm - and the other is psychological - causing the person to sense the harm. ${ }^{36}$ The last mentioned is considered to be the most important because coercion that presents itself through fear will in

30 Frías S., 'Family and Partner Violence against Women: Forced Marriage in Mexican Indigenous Communities,' International Journal of Law, Policy and The Family, vol. 31/1 (2017): 60-78.

31 Frías S., 'Family and Partner Violence against Women: Forced Marriage in Mexican Indigenous Communities,' 60-78.

32 Frías S., 'Family and Partner Violence against Women: Forced Marriage in Mexican Indigenous Communities,' 60-78.

33 Ashraf A., 'Forced Marriage and Health,' Diversity \& Equality in Health and Care, http://diversityhealthcare.imedpub.com, accessed on 1 July 2019.

34 Gill A.K. \& Hamed T., 'Muslim Women and Forced Marriages in the UK,' 540560 .

35 Nyazee I., Islamic Jurisprudence, 2nd ed. (New Delhi: Adam Publishers and Distributors, 2004), 135.

36 Gill A.K. \& Hamed T., 'Muslim Women and Forced Marriages in the UK,' 540560 . 
most instances affect the will and intention of the coerced individual/s. There may be other factors that could be associated with coercion, for, example, age, sex, strength and weakness, social standing, education, financial wellbeing as well as families that are either staunch, conservative or liberal in there thinking relating to marriage. ${ }^{37}$ We may therefore, conclude, that a party who is compelled to enter into a marriage subject to coercion, is that the pressure being enforced must cause fear to the individual/s, thereby causing harm if the individual $/ \mathrm{s}$ if they do not proceed with the intended marriage. ${ }^{38}$

Historically, in communities across the divide, it is a common practice to marry the individual $/ \mathrm{s}$, irrespective of sex predominantly at a young age. Due to the young age of the individual/s and lack of experience it would be in most instances entrusted to the elders, since it was expected (whether correctly or incorrectly) they possessed better judgement relating to marriage/ $\mathrm{s}{ }^{39}$ In addition, marriage was and is still today viewed as a union not only of the individuals, but also of a union of families, according to religious or certain customs at grassroots level. According to Roy, one reason for this is because the joint family, where generations of family members live in the same household, they are perhaps used to a particular standard of living, and perhaps acknowledging that there is a type of hierarchy within the broader family context. ${ }^{40}$ Therefore, in those communities upon marriage, historically the woman would move to the husband's home, as dictated by various customs of the various communities. This meant that the bride would not only have to adapt to the husband but also to the husband's family, whereas this would not be expected of the husband, perhaps in extreme cases this could happen, however it is uncommon. Therefore, from a community perspective it was only correct for parents or elders to accept the responsibility of selecting spouses for their sons because the bride would part of the entire family environment, rather than a wife only to her husband. ${ }^{41}$ In certain communities and perhaps from a cultural perspective, it has always been the parents' role and responsibility

37 Gill A.K. \& Hamed T., 'Muslim Women and Forced Marriages in the UK,' 540560.

38 Gill A.K. \& Hamed T., 'Muslim Women and Forced Marriages in the UK,' 540560.

39 Roy D., 'An Introduction to Forced Marriage in the South Asian Community in the United States,' Manavi Occasional Paper, No. 9 (New Jersey, USA: Manavi, Inc., 2011), 12.

40 Roy D., 'An Introduction to Forced Marriage in the South Asian Community in the United States,' 12.

41 Roy D., 'An Introduction to Forced Marriage in the South Asian Community in the United States,' 12. 
to arrange the marriage of their children..$^{42}$ In contrast, according to the U.S. Department of State, there are differences between arranged and forced marriages, highlighted as follows;

"Arranged marriages have been a long-standing tradition in many cultures and countries. The Department respects this tradition and makes a very clear distinction between a forced marriage and an arranged marriage. In arranged marriages, the families of both spouses take a leading role in arranging but the choice whether to accept the arrangement remains with the individual." 43

Nowadays, those staying (individuals or families) abroad and back home are beginning to choose their own spouses autonomously, and those who still participate in the practice of arranged marriages, in which ever form it presents itself, have a voice in the choosing of their spouses. Arranged marriages could be facilitated by way of introducing potential partners through parents, family, family friends, matrimonial websites as well as marriage brokers, however, the key points relating to choosing and consent may be one factor that separates the practice of arranged from forced marriages. ${ }^{44}$ However, there is a thin line between separating the two from each other as the distinction is not as straight forward as presented. The issue of choosing a spouse and giving and consent may be a slippery slope, for example, where one spouse may not realise that they have been forced at the time of the marriage, but only acknowledges it at a later stage. ${ }^{45}$ We will now focus on the relation between forced marriages and human rights.

\section{FORCED MARRIAGE AND HUMAN RIGHTS}

Forced marriages from a human rights perspective can be organized into broadly and crudely into the following categories, a priori - implied from the principle and posteriori - alluring to the research relating to forced marriages

42 Frías S., 'Family and Partner Violence against Women: Forced Marriage in Mexican Indigenous Communities,' 60-78.

43 U.S. Department of State Foreign Affairs Manual Volume 7 - Consular Affairs (2005), www.fam.state.gov.html, accessed on 18 November 2020.

44 Roy D., 'An Introduction to Forced Marriage in the South Asian Community in the United States,' 13.

45 Gangoli G. \& Chantler K., 'Protecting Victims of Forced Marriage: Is Age a Protective Factor?' Fem Leg Stud, vol. 17 (2009): 267-288. 
and its effects it has on the individual/s as spouses, especially women. ${ }^{46}$ From an international law perspective, forced marriages are strongly condemned. To this end, The Universal Declaration of Human Rights, article 16 states "Marriage shall be entered into only with the free and full consent of the intending spouses". ${ }^{47}$ A corresponding statement is to be found in article 23 of the International Covenant on Civil and Political Rights ${ }^{48}$, in similar vein article 10 of the International Covenant on Economic, Social and Cultural Rights ${ }^{49}$ as well as CEDAW ${ }^{50}$, article 16, well as others. ${ }^{51}$ Both the Convention on Consent to Marriage, Minimum Age for Marriage and Registration of Marriages (The Convention on Consent Marriage) ${ }^{52}$ and CEDAW, articulate that the marital contract requires the consent of the parties thereto. Furthermore, both Conventions, warrant that all State Parties take legislative action to set a minimum age to marry, as well as that marriages be registered as postulated by both conventions. ${ }^{53}$ Sadly, both conventions are silent relating to the age requirement of marriage. However, CEDAW advises that the betrothal and

46 Zebari D., 'Forced Marriage and International Human Rights,' International Journal of Humanities and Management Science, vol. 1/5 (2013): 293-295.

47 Universal Declaration of Human Rights, GA Res 217A (III), UN GAOR $3^{\text {RD }}$ Session, (Resolutions, Part1), UN Doc A/810, adopted 10 December 1948, www. un.org, accessed on 2 July 2019.

48 International Covenant on Civil and Political Rights, GA Res 2200 (XXI), UN GAOR $21^{\text {st }}$ Session, Supp No 16, UN Doc A/6316 (1996), 999 UNTS 171, adopted 16 1966, www.treaties.un.org, accessed on 2 July 2019.

49 International Covenant on Economic, Social and Cultural Rights, GA Res 2200 (XXI), UN GAOR $21^{\text {st }}$ Session, Supp No 16, UN Doc A/6316 (1996), 993 UNTS 3, adopted 16 December 1996, http://www.un.org, accessed on 2 July 2020.

50 Convention on the Elimination of All Forms of Discrimination against Women, GA Re 34/180, UN GAOR 34 ${ }^{\text {th }}$ Session, Supp No 46, UN Doc A/34/36 (1980), adopted 18 December 1979, http://www.un.org, accessed 2 July 2019.

51 Convention on Consent to Marriage, Minimum Age for Marriage and Registration, opened for signature pursuant to resolution 1763 (XVII) adopted by the General Assembly of the United Nations on 7 November 1962, entered into force 9 December 1964, http://www.un.org, accessed 2 July 2020.

52 Convention on Consent to Marriage, Minimum Age for Marriage and Registration, opened for signature pursuant to resolution 1763 (XVII) adopted by the General Assembly of the United Nations on 7 November 1962, entered into force 9 December 1964., http://www.un.org, accessed 2 July 2020.

53 Thomas C., 'Forced and Early Marriage: A Focus on Central and Eastern Europe and Former Soviet Union Countries with selected Laws from Other Countries,' $1-19$. 
marriage of a child while have no legal effect, the Convention on Consent to Marriage allows for exceptions to whatever minimum age is set. ${ }^{54}$

Regional legal instruments, for example, the Council of Europe Parliamentary Assembly Resolution $1468,{ }^{55}$ as well as the African Charter on the Rights and Welfare of the Child, ${ }^{56}$ have taken a sturdy argument relating to the age of consent to conclude a marital contract and a recommendation that the minimum age should be 18 years of age. The Council of Europe in 2005, adopted resolution 1468, relating to forced and arranged marriages. According to resolution 1468, which defines forced marriages as "the union of two persons at least one of whom has not given their full consent to the marriage". ${ }^{57}$ In addition, Resolution 1468, defines a child marriage as "the union of two persons at one of whom is under 18 years of age" ${ }^{58}$ Furthermore, Resolution 1468, amongst other issues, appeals to the national parliament of the Council of Europe member states to prescribe the minimum age for marriage at 18 years of age across the board, to make it a requirement that all marriages be announced and officially registered, and to consider the practice of forced marriages as a criminal act. ${ }^{59}$ Therefore, in light of the abovementioned argument, we could argue that forced marriages is in breach of more than any one article - more than the right of freedom - women are restricted in choosing a partner of their own as well as the freedom to live as they prefer. We will now link forced marriages to the issue of sexual slavery.

54 Thomas C., 'Forced and Early Marriage: A Focus on Central and Eastern Europe and Former Soviet Union Countries with selected Laws from Other Countries,' 1-19.

55 The Council of Europe Parliamentary Assembly Resolution 1468 adopted 5 October 2005, http://assembly.coe.int., accessed on 4 July 2019.

56 African Charter on the Rights and Welfare of the Child, OAU Doc. CAB/ LEG/24.9/49 (1990), entered into force 29 November 1999, http://wwwl.umn. edu/humanrts/africa/afchild.htm, accessed on 4 July 2019.

57 The Council of Europe Parliamentary Assembly Resolution 1468, 5 October 2005, at paragraph 4, http://www.refworld.org, accessed on 19 November 2020.

58 The Council of Europe Parliamentary Assembly Resolution 1468, 5 October 2005, at paragraph $7 \mathrm{http} / / /$ www.refworld.org, accessed on 19 November 2020.

59 The Council of Europe Parliamentary Assembly Resolution 1468, 5 October 2005, at paragraphs 14.2.1, 14.2.2 and 14.4., http://www.refworld.org, accessed on 19 November 2020. 


\section{FORCED MARRIAGE AS A FORM OF SEXUAL SLAVERY}

The link between slavery and forced marriages was highlighted in a recent report by the Special Rapporteur on Slavery, where a call was made to reconsider forced including early marriages as a form of slavery.

Under the Supplementary Convention on the Abolition of Slavery, the Slave Trade and Institutions and Practices Similar to Slavery, all forms of forced marriages are defined as practices similar to slavery, which reduce a spouse to a person over whom any or all of the powers attaching to the right of ownership is exercised. International law has further reiterated and reinforced the provisions within the Convention that prohibit forced and early marriages. ${ }^{60}$ Over the years, however, the idea that forced and early marriages are forms of slavery and, therefore, Seville marriage has been lost. ${ }^{61}$ Reaffirming forced and early marriages as slave-like practices is important as it provides an understanding of the violations that victims endure and the kind of interventions required to prevent, monitor and prosecute servile marriage. Victim protection programmes can also be specifically tailored better to support victims as servile marriage. Victims of servile marriages are often unable to escape because their families and/or the societies in which they live will not support them, whether for economic reasons, traditional, cultural, and religious beliefs. Such beliefs and practices cannot, however, be used to justify servile marriage". ${ }^{6}$

It is important to note that although forced marriages may have certain characteristics linking it to sexual slavery it should not diminish the recognition of forced marriages as a distinct and perhaps as a standalone crime. In

60 Supplementary Convention on the Abolition of Slavery, the Slave Trade, and Institutions and Practices Similar to Slavery, adopted by a Conference of Plenipotentiaries convened by Economic and Social Council resolution 608 (XXI) 30 April 1956 and done at Geneva on 7 September 1956, entry into force: 30 April 1957, in accordance with article 13, http://www.ohchr.org, accessed on 22 December 2020.

61 When a young girl or woman has no right to refuse being entered into a marriage, the marriage can be deemed a "servile marriage." In such an arrangement a young woman might be given in exchange for money or other payment; she could be sold to someone else and might be inherited by another person if her husband dies.

62 Women Living under Muslim Laws, 'Child, Early and Forced Marriage: A MultiCountry Study,' 2; United Nations General Assembly 2012 'Report of the Special Rapporteur on contemporary forms of slavery, including its causes, http://www. wluml.org, accessed on 18 November 2020. 
Prosecutor v Brima, Kamara and Kanu ${ }^{63}$ (AFRC trail), the Trail Chamber held that the evidence of forced marriages in Sierra Leone conflict was part of the crime of sexual slavery but found the defendants, three Armed Forces Revolutionary Council, guilty of war crimes and crimes against humanity, including murder, rape, sexual slavery and conscription of child soldiers. The Appeals Chamber of the Special Court for Sierra Leone reversed the Trail Chamber's dismissal of the forced marriage charge, ruling that, contrary to the majority view of the Trail Chamber, forced marriages was distinct from the crime of sexual slavery under the category of 'other inhumane acts', which recognised as crimes against humanity under customary international law. ${ }^{64}$ The Appeal Chamber judgment has been welcomed by non-governmental organisations and scholars in the continuing recognition of gender crimes. ${ }^{65}$ We will now focus on the social and historical perspectives relating to the practices of forced and arranged marriages.

\section{SOCIAL AND HISTORICAL PERSPECTIVES}

The social and historical perspectives neighbouring marriage encapsulates issues such as the age of the parties and the way in which spouses are selected, which hinges on the communities understanding of marriage, its role, structure, pattern of life, collective responsibility of its members and the individual. The social construct of marriage is often viewed historically and the concept of family as the nuclease which varies globally culturally and religiously. One might argue that the social construct of the family as a nuclease has changed globally, however, religiously and culturally remained the same. According to the WLUML, the situation in Western Europe, for instance, marriage was considered to a primarily an economic transaction where the issue of consent of women was given a low priority, in addition, women were linked with

63 Prosecutor v Brima, Kamara \& Kanu, Case No. SCSL-04-16, June 2007, (the AFRC Acussed), SCSL, $467 \mathrm{ftba} 742$, http://www.refworld.org/cases, accessed on 20 December 2020.

64 Gong-Gershowitz J., 'Forced Marriage: A New Crime against Humanity,' Northwestern Journal of International Human Rights, vol. 8/1 (2009): 53. In 2002, Physicians for Human Rights (PHR) calculated that as many as 215,000 257,000 women and girls may have been subjected to sexual violence during the armed conflict.

65 Kerr V.M., 'Should Forced Marriages be Categorised as 'Sexual Slavery' or 'Other Inhumane Acts' in International Law,' Utrecht Journal of International Law, vol. 35/1 (2020): 1-19. 
property, transferred from father, uncle, brother and son to the husband. ${ }^{66}$ This concept has changed and ushered in the more modern concept of marriage, one that is based on consent, love and individuality has now become the norm according to Western standards. Accordingly, the WLUML has highlighted the following family patterns, namely, the traditionalist, famialist, and the modern 'individualist' system. ${ }^{67}$ The traditional system is represented by the extended families, communal households, including but not limited to polygyny, authoritarian exercise by the paterfamilias, marriage at young ages, marriage partners arranged by elders, absorption of the marital couple into an existing household (in most instances the women) or non-household role or identity of women. ${ }^{68}$ The individualist system the opposite normally applies. ${ }^{69}$ The famialist model is where the family is the economic unit of production and represents wealth, social status and security for the household. In addition, fertility is somewhat exploited by marrying girls once puberty has been reached. Although these models are open to criticism and does represent the actual realities at grassroots level, it is however important to illustrate the widely held social understanding of the family. In addition, how these models can ultimately affect the lives of individuals regardless of gender. ${ }^{70}$ We will now focus on some legal initiatives advanced to regulate the practice of forced and arranged marriages.

\section{CRIMINALISING FORCED MARRIAGES: LEGAL INITIATIVES}

Most modern-day constitutions reference is made to international law, for example, the South African constitution. ${ }^{71}$ It could therefore be argued that international law constitutes a beneficial representation for countries to aspire

66 Women Living under Muslim Laws, 'Child, Early and Forced Marriage: A MultiCountry Study,' 11.

67 Women Living under Muslim Laws, 'Child, Early and Forced Marriage: A MultiCountry Study,' 11.

68 Women Living under Muslim Laws, 'Child, Early and Forced Marriage: A MultiCountry Study,' 11.

69 Macfarlane A 1986 Marriage and love in England: Modes of Reproduction 13001840. Basil Blackwell Ltd, Unicef 200. Early Marriage: Child Spouses. Innocenti Digest No.7. Unicef Innocenti Research Centre, http://www.unicef-irc.org, accessed on 20 November 2020.

70 Women Living under Muslim Laws, 'Child, Early and Forced Marriage: A MultiCountry Study,' 11.

71 Constitution of the Republic of South Africa of 1996, Chapter 3, articles 1-5, http://www.justice.gov.za, accessed on 19 November 2020. 
to as a model. This may help with the argument why governments are trying to find solutions, preventing the practice of forced marriages, in the same vein being sensitive to global cultural and ethnic diversity of communities in a country not of originality.

From a national law perspective, solutions to prevent forced marriages can be more specific than international law, thus it could inflict serious animosity in communities in which the practice of forced and arranged marriages are taking place, thereby being perhaps culturally insensitive. In addition, most national legislation in countries could also include provisions that may apply extra-territorially, and the international community may exert pressure on those countries to enact legislation to tackle these practices. ${ }^{72}$ European countries such as Belgium, Norway and Germany, have resorted to institute legislative measures which would render forced marriage/s as a criminal offence. $^{73}$ In 2005, the UK government conducted a national consultation on whether a specific criminal offence of forced marriage would assist in the prevention of this. ${ }^{74}$ This has led to various persuasive arguments from various communities within the borders of the UK. ${ }^{75}$ Key organisations that were against the criminalisation of forced marriages, suggested a form of civil protection, postulating that it would be about protection and prevention instead of punishment. ${ }^{76}$

Those for the proposed legislation argued that criminalising the practice of forced marriages could act as a defensive measure, as it could be viewed by those in such a predicament as leverage of being forced to marry. ${ }^{77}$ Having legislation could inspire confidence to those in such a predicament and the

72 Zebari D., 'Forced Marriage and International Human Rights,' 293-295. According to statistics, approximately 300 cases of forced marriages are reported to official institutions in the U.K. every year.

73 Zebari D., 'Forced Marriage and International Human Rights,' 293-295.

74 Chantler K., Gangoli G. \& Hester M., 'Forced Marriage in the UK: Religious, Cultural, Economic or State Violence?' Feminist Legal Studies, vol. 17 (2009): 267-288; Gaffney-Rhys Report for the Office of the High Commissioner for Human Rights Forced Marriages in England and Wales: Challenges, Achievements, Best Practices and Implementation Gaps, http://www.ohchr.org, accessed on 20 December 2020.

75 Gaffney-Rhys Report for the Office of the High Commissioner for Human Rights Forced Marriages in England and Wales: Challenges, Achievements, Best Practices and Implementation Gaps, http://www.ohchr.org, accessed on 18 November 2020.

76 The Forced Marriage (Civil Protection Act of 2007).

77 Chantler K., Gangoli G. \& Hester M., 'Forced Marriage in the UK: Religious, Cultural, Economic or State Violence?' 267-288. 
possibility that these case/s falling in a certain category could lead itself to prosecution..$^{78}$ Opposing arguments against the proposed legislation postulated that victims may not come forward fearing that their families would be prosecuted, parents may resort to taking the children back to their home of origin and criminalisation may cause conflict that may be difficult to bridge where parents may be viewed by the community as persons as being not law abiding citizens, which would carry a certain type of stigma. ${ }^{79}$ In addition, in the UK, the annulment is made easier, if it is reported that any party was forced and that consent was lacking at the time, which culminated into a forced marriage. According to Zebari, as soon as protective measures are assumed, a possible breeding ground of animosity may manifest itself, for example, proposed legislation may be guilty of contravening international law if the parties state that the marriage was a forced marriage at the registry office, thereby discriminating against immigrants who wish to celebrate the union according to their beliefs, customs or religion. ${ }^{80}$ Furthermore, those communities, in which those marriages take place will be under constant surveillance by the registry. Furthermore, children of immigrants may be prevented from travelling upon suspicion of possible forced marriages, for example, increasing the age of sponsorship and spousal visas from 18 to 21 years. ${ }^{81}$

\section{CONCLUSION}

It may be argued that forced and arranged marriages are perhaps so strongly embedded in certain communities, that these communities observe it as part their culture or religion. Therefore, there is a possibility that these communities see no violation of any man-made law. This does pose significant obstacles for governments and communities. On the one hand, a government would or could be pressured to introduce legislative measure to combat or perhaps regulate these practices. On the other hand, communities may view these initiatives as a clear violation of one of the most basic and fundamental rights, such as the right to practice either their religion or culture.

This article has highlighted that these practices does happen and affects the global community in one way or the other. In addition, certain legislative

\footnotetext{
78 Zebari D., 'Forced Marriage and International Human Rights,' 293-295.

79 Zebari D., 'Forced Marriage and International Human Rights,' 293-29.

80 Zebari D., 'Forced Marriage and International Human Rights,' 293-295.

81 Chantler K., Gangoli G. \& Hester M., 'Forced Marriage in the UK: Religious, Cultural, Economic or State Violence?' 267-288.
} 
initiatives may be found to be discriminatory in nature, as these initiatives may focuses on a particular community which may create animosity towards the state. So the question how do we proceed? I am of the opinion, that these practices must be addressed as grassroots level. The role of NGO's, families and religious leaders must play a more active and a visible role in educating communities of the effects of their decisions. For example, the mental and physical aspects which their children will be and perhaps experiencing. However, these practices may never be eradicated, but at least we could change the mind-set of parents, families and friends and bring awareness to communities to think before embarking on these practices.

\section{REFERENCES}

Burkert W., Creation of the Sacred: Tracks of Biology in Early Religions (Cambridge, Massachusetts: Harvard University Press, 1996).

Chantler K., 'Recognition of and Intervention in Forced Marriages as a Form of Violence and Abuse,' Sage Journals: Trauma, Violence, \& Abuse, vol. 13/3 (2012): 176-183.

Chantler K., Gangoli G. \& Hester M., 'Forced Marriage in the UK: Religious, Cultural, Economic or State Violence?' Feminist Legal Studies, vol. 17 (2009): 267-288.

Cohn H., 'Religious Human Rights,' 19 Dine Israel 101 (1997-1998), http:// religionhumanrights.org, accessed on 19 June 2019.

Frías S., 'Family and Partner Violence against Women: Forced Marriage in Mexican Indigenous Communities,' International Journal of Law, Policy and The Family, vol. 31/1 (2017): 60-78.

Gangoli G. \& Chantler K., 'Protecting Victims of Forced Marriage: Is Age a Protective Factor?' Fem Leg Stud, vol. 17 (2009): 267-288.

Gill A.K. \& Hamed T., 'Muslim Women and Forced Marriages in the UK,' Journal of Muslim Minority Affairs, vol. 36/4 (2016): 540-560.

Gong-Gershowitz J., 'Forced Marriage: A New Crime against Humanity,' Northwestern Journal of International Human Rights, vol. 8/1 (2009): 53-76.

Kaplan Y.S., 'A Father's Consent to the Marriage of his Minor Daughter: Femininsm and Multiculturalism in Jewish Law,' Review of Law and Social Justice, vol. 18/2 (2009): 393-460.

Kerr V.M., 'Should Forced Marriages be Categorised as 'Sexual Slavery' or 'Other Inhumane Acts' in International Law,' Utrecht Journal of International Law, vol. 35/1 (2020): 1-19. 
Kuper A., Culture: The Anthropologists'Account (Massachusetts: Harvard University Press, 1999).

Mtshali V., 'Forced Child Marriage Practiced under the Pretext of Customary Marriage in South Africa,' Child Abuse Research: A South African Journal, vol. 15/2 (2014): 51-61.

Nyazee I., Islamic Jurisprudence, $2^{\text {nd }}$ ed. (New Delhi: Adam Publishers and Distributors, 2004).

Raday F., 'Culture, Religion, and Gender,' International Journal of Constitutional Law, vol. 1/4 (2003): 663-715.

Reddy R., 'Gender, Culture and the Law: Approaches to Honour Crimes in the UK,' Feminist Legal Studies, vol. 16/3 (2008): 305-321.

Sabbe A., Temmerman M., Brems E. \& Leye E., 'Forced Marriage: An Analysis of Legislation and Political Measures in Europe,' Crime, Law and Social Change, vol. 62/2 (2014): 171-189.

Zebari D., 'Forced Marriage and International Human Rights,' International Journal of Humanities and Management Science, vol. 1/5 (2013): 293295.

African Charter on the Rights and Welfare of the Child, OAU Doc. CAB/ LEG/24.9/49 (1990), entered into force 29 November 1999, http:// wwwl.umn.edu/humanrts/africa/afchild.htm, accessed on 4 July 2019.

Ashraf A., 'Forced Marriage and Health,' Diversity \& Equality in Health and Care, http://diversityhealthcare.imedpub.com, accessed on 1 July 2019.

Convention on Consent to Marriage, Minimum Age for Marriage and Registration, opened for signature pursuant to resolution 1763 (XVII) adopted by the General Assembly of the United Nations on 7 November 1962, entered into force 9 December 1964, http://www.un.org, accessed on 2 July 2019.

Gaffney-Rhys Report for the Office of the High Commissioner for Human Rights Forced Marriages in England and Wales: Challenges, Achievements, Best Practices and Implementation Gaps, http://www. ohchr.org, accessed on 18 November 2020.

International Covenant on Civil and Political Rights, GA Res 2200 (XXI), UN GAOR $21^{\text {st }}$ Session, Supp No 16, UN Doc A/6316 (1996), 999 UNTS 171, adopted 16 1966, http://www.un.org, accessed on 2 July 2019.

International Covenant on Economic, Social and Cultural Rights, GA Res 2200 (XXI), UN GAOR 21 ${ }^{\text {st }}$ Session, Supp No 16, UN Doc A/6316 (1996), 993 UNTS 3, adopted 16 December 1996, http://www.un.org, accessed on 2 July 2020. 
Convention on the Elimination of All Forms of Discrimination Against Women, GA Re 34/180, UN GAOR 34 ${ }^{\text {th }}$ Session, Supp No 46, UN Doc A/34/36 (1980), adopted 18 December 1979, http://www.un.org, accessed 2 July 2019.

Macfarlane A 1986 Marriage and Love in England: Modes of Reproduction 1300-1840. Basil Blackwell Ltd, Unicef 200. Early marriage: Child spouses. Innocenti Digest No.7. Unicef Innocenti Research Centre, http://www.unicef-irc.org, accessed on 20 November 2020.

Roy D., 'An Introduction to Forced Marriage in the South Asian Community in the United States,' Manavi Occasional Paper, No. 9 (New Jersey, USA: Manavi, Inc., 2011).

Supplementary Convention on the Abolition of Slavery, the Slave Trade, and Institutions and Practices Similar to Slavery, adopted by a Conference of Plenipotentiaries convened by Economic and Social Council resolution 608 (XXI) 30 April 1956 and done at Geneva on 7 September 1956, entry into force: 30 April 1957, in accordance with article 13, http:// www.ohchr.org, accessed on 22 December 2020.

The Convention on the Rights of the Child, GA Res 44/24, annex, 44 U.N. GAOR Supp. (No. 49) at 167, UN Doc. A/44/49 (1989) entered into force 2 September 1990, in accordance with article 49, http://www. unhchr.ch, accessed on 2 July 2019.

The Council of Europe Parliamentary Assembly Resolution 1468 adopted 5 October 2005, http://assembly.coe.int., accessed on 4 July 2019.

The Council of Europe Parliamentary Assembly Resolution 1468, 5 October 2005, http://www.refworld.org, accessed on 19 November 2020.

Thomas C., 'Forced and Early Marriage: A Focus on Central and Eastern Europe and Former Soviet Union Countries with selected Laws from Other Countries,' United Nations Division for the Advancement of Women (2009): 1-19.

U.S. Department of State Foreign Affairs Manual Volume 7 - Consular Affairs (2005), www.fam.state.gov.html, accessed on 18 November 2020.

Universal Declaration of Human Rights, GA Res 217A (III), UN GAOR $3^{\text {RD }}$ Session, (Resolutions, Part1), UN Doc A/810, adopted 10 December 1948, http://www.un.org, accessed on 2 July 2019.

Women Living under Muslim Laws, 'Child, Early and Forced Marriage: A Multi-Country Study,' A Submission to the UN Office of the High Commissioner on Human Rights (OCHCR) (London: Women Living under Muslim Laws, 2013). 


\section{STATUTES}

The Forced Marriage (Civil Protection Act of 2007).

The Republic of South Africa Constitution of 1996.

\section{CASES}

Prosecutor v Brima, Kamara \& Kanu, Case No. SCSL-04-16, June 2007 (AFRC trail). 
Jurnal Syariah, Jil. 29, Bil. 1 (2021) 21-42 